\title{
O CASO RIGGS VS. PALMER COMO UM “MODELO" ADEQUADO PARA DECIDIR SOBRE OS DIREITOS FUNDAMENTAIS NO PANORAMA DA CONSTITUCIONALIZAÇÃO DO DIREITO NO BRASIL ${ }^{1}$
}

\author{
THE CASE RIGGS VS. PALMER AS AN APPROPRIATE "MODEL" TO DECIDE ABOUT \\ FUNDAMENTAL RIGHTS IN THE OVERVIEW OF CONSTITUTIONALIZATION OF BRAZILIAN LAW
}

\author{
Wilson Engelmann ${ }^{2}$ \\ Raquel von Hohendorff ${ }^{3}$ \\ Paulo Júnior Trindade dos Santos ${ }^{4}$
}

\begin{abstract}
Resumo: Este artigo tem como tema a análise do caso Riggs vs. Palmer, famoso por mudar o entendimento das leis sucessórias norte-americanas e que proporcionou o estudo sobre o papel dos princípios no Direito em Ronald Dworkin. Por meio da avaliação do caso concreto busca-se demonstrar as possibilidades e contribuições do "modelo decisório" norte-americano para o sistema jurídico brasileiro, especialmente no relativo ao "direito fundamental a uma decisão judicial estruturada", constitucionalmente garantido, e não uma decisão que dependa da vontade do magistrado. $O$ método utilizado é o fenomenológico hermenêutico a partir de Hans-Georg Gadamer, em que o pesquisador está relacionado ao objeto de estudo. Objetiva-se apresentar características do caso Riggs vs. Palmer, estudar o papel dos princípios na construção do movimento de constitucionalização do Direito e do Direito Privado em especial e seus limites, bem como avaliar o papel da dignidade da pessoa humana na estruturação do diálogo entre as fontes do Direito, como um caminho para reposicionar
\end{abstract}

a Constituição para o centro do sistema jurídico, (re)valorizando-se as possibilidades jurídicas do conjunto das fontes do Direito para dar respostas adequadas às características do caso concreto. Ao final, constatam-se evidências de que a constitucionalização do Direito Privado não é a solução para todos os casos, que o Código Civil e outros textos do Direito Privado ainda deverão ser valorizados, e que a aplicação da dignidade da pessoa humana, apesar da sua centralidade na CF de 1988, é a fundamentação para decisões de situações da vida muito diversificadas, aproximando-se da banalização de seu emprego.

Palavras-chave: Caso concreto. Decisão. Princípios. Constituição. Dignidade da pessoa humana.

\footnotetext{
Resultado parcial dos projetos de pesquisa desenvolvidos pelos autores, que são intitulados: (a) "As transformações jurídicas das relações privadas: a construção de marcos regulatórios e a revisão de categorias tradicionais do Direito como condição de possibilidade para atender aos desafios das mutações jurídicas contemporâneas geradas pelas novas tecnologias" (UNISINOS); (b) "Observatório dos Impactos Jurídicos das Nanotecnologias: em busca de elementos essenciais para o desenvolvimento do diálogo entre as Fontes do Direito a partir de indicadores de regulação às pesquisas e produção industrial com base na nano escala", Edital Universal CNPq 14/2014.

2 Doutor e Mestre em Direito pela Universidade do Vale do Rio dos Sinos; Professor e Pesquisador do Programa de Pós-Graduação em Direito na Universidade do Vale do Rio dos Sinos; Avenida Unisinos, 950, Cristo Rei, 93022-750, São Leopoldo, Rio Grande do Sul, Brasil; wengelmann@unisinos.br

Mestre e doutoranda em Direito Público pela Universidade do Vale do Rio dos Sinos; Professora na Universidade do Vale do Rio dos Sinos; vetraq@gmail.com

4 Mestre e doutorando em Direito Público pela Universidade do Vale do Rio dos Sinos; Professor na Universidade do Vale do Rio dos Sinos; pjtrindades@hotmail.com
} 


\begin{abstract}
This article focuses on the analysis of the case Riggs vs. Palmer, renowned for changing the understanding of North American succession laws that provided the study on the role of the principles in law in Ronald Dworkin. Through the evaluation of the case seeks to demonstrate the possibilities and contributions of the "decision-making model" US to the Brazilian Legal System, especially concerning the "fundamental right to a structured judicial decision", constitutionally guaranteed and not a decision that depends the will of the Magistrate. The method used is the hermeneutic phenomenological from Hans-Georg Gadamer, where the researcher is related to the subject matter. Aims to present case features Riggs vs. Palmer, studying the role of the principles in the construction of constitutionalising movement of law and private law in particular and its limits and to evaluate the role of human dignity in structuring the dialogue between sources of law, as a way to reposition the Constitution to the center of the legal system, (re)valuing the legal scope of the sources of the Law set to give appropriate responses to the specific case characteristics. In the end, exhibit evidence that constitutionalization of Private Law is not the solution for all cases; and the Civil Code and other legal texts of Private Law should still be valued and that the application of human dignity, despite its centrality in the 1988 CF is the basis for the very diversified life situations decisions, approaching the trivialization of their application.
\end{abstract}

Keywords: Case. Decision. Principles. Constitution; Dignity of human person.

\title{
Introdução
}

O caso concreto que sustenta este artigo tem origem no Direito Americano. Por isso, inicialmente se deverá deixar assentada a conhecida diferença entre o Sistema Jurídico da Civil Law e o Sistema Jurídico da Common Law. Não se deve esquecer das diferenças, especialmente aquelas vinculadas à tradição do sistema americano, aspectos sociais e o cuidado nas condições para a formação dos precedentes. Apesar disso, atualmente, existem cada vez mais elementos comuns entre os dois sistemas.

É justamente na construção das diferenças intersistêmicas que se pretende situar este trabalho, buscando evidenciar possibilidades e contribuições do "modelo decisório" norte-americano para o sistema jurídico brasileiro, notadamente na aplicação judicial dos direitos fundamentais, com destaque para o "direito fundamental a uma decisão judicial estruturada" a partir dos comandos constitucionais. Vale dizer, o magistrado, independente do grau de jurisdição, deverá observar o horizonte hermenêutico de sentido já produzido pelas fontes de Direito sobre a matéria, vedando-se uma fundamentação que somente dependa da "vontade do magistrado". Metodologicamente, este artigo é sustentado na fenomenologia hermenêutica gerada a partir de Martin Heidegger e Hans-Georg Gadamer. Ressalta-se que não se fará uma análise externa, como se o sujeito e o objeto estivessem cindidos. Pelo contrário, o sujeito (o pesquisador) está diretamente implicado, pois relacionado com o objeto de estudo, o qual interage com ele e sofre as consequências dos seus resultados (suas descobertas e potencialidades). Assim, não se trata de uma investigação alheia ao pesquisador; ele está no mundo onde a pesquisa será desenvolvida. Aí o significado do fenômeno. Já essa constatação fenomênica receberá a atribuição de sentido, a partir do círculo hermenêutico.

Gadamer (2002, p. 64) questionou a visão de que o método poderia, de forma exclusiva, garantir a validade universal e a verdade, e também questionou se, realmente, o método teria lugar nas Ciências do Espírito. As Ciências do Espírito não podem ser pensadas do mesmo modo que as 
Ciências da Natureza. Há algo que "não pode ser medido pela verificabilidade de um enunciado" (GADAMER, 2002, p. 64), pois "todo enunciado tem pressupostos que ele não enuncia", uma motivação, um horizonte de sentido que nasce na situação da pergunta (GADAMER, 2002, p. 67). Assim, métodos seguros não têm força para afastar preconceitos em busca da objetividade nas ciências do espírito; essa é uma ilusão. No movimento do círculo hermenêutico, em que a pré-compreensão antecede a compreensão/interpretação/aplicação que dará sentido aos resultados da pesquisa na qual o investigador estará diretamente implicado. Portanto, isso somente será possível a partir da experiência do pesquisador, mediante sua pré-compreensão de mundo, da vida e dos resultados que a pesquisa poderá produzir na sociedade.

A construção do artigo se valeu das seguintes fontes: pesquisa bibliográfica, legislativa e jurisprudencial. $\bigcirc$ problema que orientou a pesquisa pode ser definido da seguinte maneira: sob quais condições o caso Riggs vs. Palmer poderá orientar a construção de modelo jurídico para se conservar a fundamentalidade constitucional da dignidade da pessoa humana, no panorama da chamada constitucionalização do Direito Privado?

A partir desse problema, desenha-se a hipótese da investigação: a constitucionalização do Direito Privado deverá ser examinada com cautela, sob pena de destruir as bases e os institutos próprios do Direito Privado, em nome de uma constitucionalização sem limites e critérios, colocando em risco as características jurídicas que distinguem o Direito Público do Direito Privado. A dignidade da pessoa humana não poderá ser usada como um escudo que seja capaz de assegurar a proteção de toda e qualquer demanda oriunda da sociedade. Para tanto, as decisões judiciais no Brasil deverão ser fundamentadas adequadamente, em atenção a esse direito fundamental inserido na Constituição do Brasil, observando o horizonte hermenêutico já construído para o tema a ser decidido, na tentativa de continuar a linha decisória trazida pela tradição. Aí o ponto fulcral que se pode aprender das decisões proferidas no Sistema Jurídico da Common Law.

São objetivos neste artigo: conhecer algumas características do caso Riggs vs. Palmer, que desencadeou o estudo sobre o papel dos princípios no Direito na obra de Ronald Dworkin; estudar o papel dos princípios na construção do movimento de constitucionalização do Direito e do Direito Privado em especial e seus limites; e avaliar o papel da dignidade da pessoa humana na estruturação do diálogo entre as fontes do Direito, como um caminho para reposicionar a Constituição para o centro do sistema jurídico, (re)valorizando-se as possibilidades jurídicas do conjunto das fontes do Direito para dar respostas adequadas às características do caso concreto.

\section{Algumas características do caso Riggs vs. Palmer: desvelando o papel dos princípios na construção do conteúdo do direito}

O caso norte-americano Riggs vs. Palmer, de 1889, gerou transformações no Direito sucessório americano. Por isso, ele é alçado como um paradigma para o Direito brasileiro e o movimento 
de sua constitucionalização, ainda não integralmente compreendido pelos atores jurídicos nacionais (CASO RIGSS vs. PALMER, 2016; ENGELMANN, 2001, p. 141-143). Tal situação foi o que chegou na Court of Appeals de Nova Iorque em meados de 1889; Riggs vs. Palmer 115 N.Y. 506 (1889), caso que viria a iniciar uma transformação histórica nas leis sucessórias nos Estados Unidos. Até aquele momento, as cortes americanas nunca haviam registrado casos desse tipo (CASO RIGSS vs. PALMER, 2016), exceto o caso similar de Owens vs. Owens (2016), recebido em torno de um ano antes pela Suprema Corte da Carolina do Norte.

Existe, porém, uma controvérsia acerca da afirmação de que outros casos desse caráter não houvessem sido registrados pelas cortes, pois em meio à guerra civil e outros acontecimentos sociais na época, a herança fazia parte da cultura e representava uma potencial mudança de status econômico para muitos descendentes. Entende-se que o Direito Sucessório nos Estados Unidos varia de um Estado para outro e que vem sendo moldado ao longo dos séculos. ${ }^{5} \mathrm{O}$ surgimento de crimes dessa natureza, concomitantemente com o nascimento de apólices de seguro de vida, levaram as cortes americanas, em certas ocasiões, a uma (re)consideração do comportamento do(s) beneficiário(s), reavaliando o propósito e a função dos testamentos e a própria manifestação de vontade por eles grifados.

Em Riggs vs. Palmer, a autora do litígio foi uma das filhas de Francis Palmer, Mrs. Riggs. O caso foi apelado pelo réu Elmer Palmer, neto do falecido Francis Palmer, e também seu assassino, que veio em segunda instância pleitear a decisão da Corte Superior que lhe negara o recebimento da herança, vontade que seu avô havia deixado registrado em testamento.

Os fatos decorrem do assassinato de Francis Palmer, que fora envenenado por seu neto Elmer Palmer, o beneficiário de uma pequena fortuna acumulada por seu avô. Elmer, que vivia com seu avô na época de seu assassinato e sabia da existência do testamento, veio a envenenar-lhe logo após o novo casamento de seu avô Francis, que era viúvo, porém adentrava em um pacto antenupcial com sua nova esposa; tal mudança traria a Elmer a perda dos bens de seu avô perante o seu falecimento.

O juiz Robert Earl (BENIGNO, 2016) escreveu em sua decisão que, diante da reivindicação da propriedade por Elmer, à Corte apenas restaria perguntar-se: terá Elmer, nessas circunstâncias, o direito de receber a herança?

A análise da Corte fundamenta que para tal acontecimento existe uma lógica a ser considerada. De fato, é verdade que o propósito dos estatutos que regulam a confecção, a prova e os efeitos dos testamentos é garantir que tais vontades não sejam objeto de fraude e que consigam produzir efeitos legais aos últimos desejos expressos do testador, e que, assim, não podem ser alterados ou violados. ${ }^{6}$

\footnotetext{
5 Acerca do histórico das leis sucessórias nos Estados Unidos, ver: Libray ff Congress (2016).

6 As normas relativas aos testamentos indicam as formalidades que devem ser respeitadas para a sua validade. No entanto, a lei de sucessão de Nova York, que deveria ser aplicada ao caso, nada estipulava quanto à possibilidade de o testamento ser cumprido ou não se uma pessoa mencionada nele houvesse assassinado o testador. $\bigcirc$ advogado de Elmer, alegando a lacuna na lei, defendia que o cliente deveria ter o seu legado (ENGELMANN, 2001, p. 141).
} 
Foi intenção do legislador expressar que os beneficiários recebessem a herança a eles legalmente designada. Mas a intenção do legislador jamais poderia ter sido em favor da entrega dos bens ao beneficiário que matara o seu doador. E se tivessem previsto tal possibilidade, teriam providenciado regular esse plano. A Corte entende que quem escreve as leis nem sempre consegue se expressar perfeitamente ou prever todos os cenários que nunca tenham ocorrido de fato; às vezes podem se exceder no texto ou, ainda, não ter suficiente provisão. Portanto, os juízes devem desenvolver métodos para avaliar essas situações não previstas por provável e racional conjuntura, a chamada interpretação racional. A Corte percebe que para se obter uma justa e adequada decisão, é necessário colocar-se no lugar do legislador e perguntar-se se na criação da lei havia refletido e compreendido tal caso.

Além disso, todas as leis, bem como os contratos, devem ser controlados em suas operações e efeitos pelo geral e fundamento máximo do Sistema Jurídico da Common Law, ou seja, à pessoa nenhuma deve ser permitido lucrar por fraude própria, ou se aproveitar por erros, ou ainda reivindicar qualquer bem diante da sua própria iniquidade e adquirir propriedade por seu próprio crime. Esse fundamento está ditado nas políticas públicas e tem sua base nas leis universais administradas em todos os países civilizados, assim, sobressaindo-se mesmo sobre regras legisladas. Eis um exemplo de caso concreto em que estes foram os fundamentos aplicados: na decisão do caso New York Mutual Life Insurance Company vs. Armstrong (117 U. S. 591) (LAW RESOURCE, 2016). Nesse caso, decidiu-se que uma pessoa não pode receber a apólice a ela designada se ela mesma cometeu o crime, sendo essa uma forma de fraudar seus direitos a fim de assegurar tal pagamento. É um horizonte da tradição que é percebido e avaliado pelo julgador no momento em que um caso concreto é decidido.

É pelas razões citadas que o Juiz Earl entendeu que Elmer não deveria receber a propriedade de herança, pois o testador poderia ainda estar vivo ou mesmo o beneficiário poderia ter falecido antes do doador. Logo, seu ato forjou a aparição de um direito que talvez não viesse a ser consumado. Na opinião de Earl, essa decisão não impõe uma punição mais grave ao que já lhe foi dado penalmente para o crime de homicídio: simplesmente sustenta que ele não deve se beneficiar de sua torpeza.

Sobre o voto do Juiz Earl, Engelmann (2001, p. 143, grifo nosso) destaca:

O juiz Earl, usando o argumento de que era necessário considerar as intenções do legislador como de especificar a verdadeira lei, votou em sentido diferente. Isto significa dizer que é necessário pensar um pouco mais além das meras palavras utilizadas pelo legislador. Além destes aspectos, o juiz entendia que deveria ser mensurado o contexto histórico no momento de ser interpretada a lei. Além disso, defendia, igualmente, que fossem levados em conta os chamados princípios gerais do direito. Isto representava considerar os princípios de justiça pressupostos em outras partes do direito. Dentro desta linha de ideias, o juiz defendia que "o direito respeita o princípio de que ninguém deve beneficiar-se de seu próprio erro". Desta maneira, a lei sucessória deveria ser interpretada no sentido de negar a herança para aquele que tivesse cometido um homicídio para facilitar o seu recebimento. Este voto foi seguido por outros juízes, fazendo com que Elmer não recebesse a sua parte que havia sido destinada no testamento. 
Apesar de a decisão da Corte ter sido de manter o já decidido pela corte inferior, o voto do Juiz Gray ${ }^{7}$ se opôs à decisão majoritária, fundamentando que se o legislador não havia mencionado esse tipo de situação nas leis era porque entendia que tal situação não deveria atrapalhar a função do testamento. Assim, mesmo se o testador mudasse de ideia se soubesse que o beneficiário o mataria pela herança, esta não era a questão em jogo. Ainda, sobre o voto do Juiz Gray, pode-se dizer que ele "defendeu a ideia da chamada teoria da interpretação literal, em que os termos da lei devem ser examinados de modo a afastar qualquer informação especial sobre o contexto de seu uso ou as intenções de seu autor. ${ }^{8}$

Sobre o referido voto do Juiz Gray, importante mencionar a análise desenvolvida por Engelmann (2001, p. 145-146):

Além do mais, dentro desta linha de análise, o juiz nada mais é do que uma espécie de intérprete delegado da vontade que ditou a norma. Esta, por sua vez, exige uma adesão formal e externa à sua vontade, ou seja, afasta qualquer consideração sobre a conduta efetiva do homem. A proposta de Hans Kelsen, que é aceita em grande parte por Norberto Bobbio, procura conectar, numa perspectiva estritamente formalista, o texto da regra aos contornos da situação concreta. O voto do juiz Gray retrata esta peculiaridade ao entender que, como a lei não continha nenhuma exceção expressa sobre o caso de assassinos, deveria ser aplicada de acordo com a sua redação. Vale dizer que o que está formulado deve ser obedecido, de acordo com os critérios fornecidos pelo modelo subsuntivo (lei $\mathrm{x}$ fato concreto $=$ decisão judicial). A justiça neste voto nada mais é do que a adequação da conduta ao enunciado do texto legal. Destarte, nasce uma concepção estritamente convencional da justiça, pois esta será implementada a partir do momento em que o Poder Judiciário aplica os contornos da lei, desconsiderando qualquer contribuição axiológica. O voto do juiz Gray, no caso Riggs vs. Palmer, retrata a concepção fundada a partir de Thomas Hobbes. Esta manifestação judicial busca, ao subliminar a concepção monista das fontes do direito, o apego exclusivo ao texto legal, e mais do que isto, valoriza apenas o contexto das palavras escritas num pedaço de papel que receberam a chancela do poder Legislativo.

É desse caso que Dworkin (2010, p. 36, grifo nosso) se utiliza para a análise dos princípios, mencionando:

Denomino política aquele tipo de padrão que estabelece um objetivo a ser alcançado, geralmente a melhoria em algum aspecto econômico, político ou social da comunidade (embora alguns objetivos sejam negativos, no sentido de que eles estipulam que algum aspecto presente deve ser protegido contra mudanças adversas). Denomino "princípio" um padrão que deve ser observado, não porque irá promover ou assegurar uma situação econômica, política ou social considerada desejável, mas porque é uma exigência de justiça ou equidade ou alguma outra dimensão da moralidade. Assim, o padrão que estabelece que os acidentes devem ser reduzidos é uma política e o padrão segundo o qual nenhum homem deve beneficiar-se de seus próprios delitos é um princípio.

\footnotetext{
7 "O voto do juiz Gray, no caso Riggs vs. Palmer, retrata a concepção fundada a partir de Thomas Hobbes. Esta manifestação judicial busca, ao subliminar a concepção monista das fontes do direito, o apego exclusivo ao texto legal, e mais do que isto, valoriza apenas o contexto das palavras escritas num pedaço de papel que receberam a chancela do poder Legislativo." (ENGELMANN, 2001, p. 145).

8 "Observando-se a lei sucessória sob este ângulo, deveria ser concluído que ela não continha exceções para os assassinos. Assim, Elmer deveria receber a sua parte no patrimônio." (ENGELMANN, 2001, p. 142).
} 
Conforme Dworkin (2010, p. 36), o tribunal iniciou com a seguinte admissão: "é bem verdade que as leis que regem a feitura, a apresentação de provas, os efeitos dos testamentos e a transferência de propriedade, devem ser interpretadas literalmente e se sua eficácia e efeito não podem, de modo algum, e em quaisquer circunstâncias, ser limitados ou modificados." Segundo o autor, o tribunal partiu do pressuposto de que todas as leis e contratos podem ser limitados na sua execução e seu efeito por máximas gerais e fundamentais do direito costumeiro (DWORKIN, 2010, p. 36). Vislumbra-se o desenho de um efetivo princípio estruturante dos Direitos Fundamentais, que substancializam a construção do Direito a partir da atividade jurisdicional. Examinando o caso a partir dos pressupostos da hermenêutica filosófica, pode-se identificar alguns aspectos, como segue:

[...] interpretada a regra a partir da suficiência ôntica, o assassino teria direito à herança. Aliás, parte do Tribunal posicionouse favorável a essa leitura. Entretanto, ficou decidido, a partir do princípio de que ninguém pode lucrar com sua própria fraude, ou beneficiarse de atos ilícitos, que o assassino não receberia a herança. O exemplo retirado do caso Riggs v.s. Palmer parece simples se descolado do ano em que foi discutido (1889) e da tradição americana acerca das disposições sucessórias, diferentes da tradição brasileira, por exemplo. No caso estadunidense - e isso pode ser notado no clássico de Alexis de Tocqueville, A democracia na America -, havia - e ainda há - uma forte tradição no sentido de prevalecer o efeito de fragmentação patrimonial nas leis sucessórias. Ou seja, a tradição americana apontava para a não conservação familiar do patrimônio. Daí a não previsão de disposições que anulassem os efeitos do testamento (mormente levando em conta uma exceção desse jaez). (STRECK, 2011, p. 574-575).

O tratamento judicial dado ao caso evidencia a porosidade da regra e o caráter de fechamento do princípio. Embora fosse desejável a fragmentação do patrimônio - enquanto ideologia liberal -, há limites para tanto, e, assim, tratase da necessária constatação de que um país e sua democracia não podem ser construídos a partir de fraudes e iniquidades. O caso em exame destaca a prevalência de princípios cravados na essência constitucional de um país, proporcionando um necessário filtro de constitucionalização, inclusive nas decisões judiciais, em que, na entrada, tem-se uma regra expressa.

[...] Isso é próprio da virtuosidade dos princípios. O mundo prático, isto é, a manifestação existencial de uma comunidade de princípios, dáse não simplesmente por intermédio de categorias ou enunciados assertóricos. Na verdade, a virtude republicana aponta para limitações do código licito/ilícito (ou seja, o que não é proibido é permitido), isto é, o que não está vedado na lei dos testamentos estaria permitido. Ora, esse é o caráter de "universalização" do exemplo, uma vez que é impossível um sistema jurídico prever as inúmeras hipóteses de incidência de regras jurídicas. (STRECK, 2011, p. 574-575, grifo nosso).

A vida humana não nasce com um manual de instruções. A criatividade do ser humano cria situações que não têm previsão expressa na regra. Nesse caso, como resolver? Deixar ao poder discricionário do magistrado? Ao seu instinto de justiça ou de moral? Não, para todas as perguntas. 
A resposta deverá ser construída a partir do horizonte de sentido já instaurado no Direito da sociedade, mediante a orientação dos princípios inseridos no texto constitucional.

[...] A disposição testamentária do direito norteamericano não tratava do testamento objeto do litígio de Riggs v.s. Palmer, mas, sim, do conjunto dos testamentos feitos por toda a sociedade americana. A concreta normatividade do fenômeno jurídico somente ocorre - como ocorreu no referido case - com a incidência principiológica. Notese que, no exemplo em tela, a regra sobre os testamentos continua existindo (e valendo). Somente para esse caso específico é que ela não poderia ser aplicada, criandose, a partir disso, uma nova norma, segundo a qual não se cumprem as disposições testamentárias se originárias de ato criminoso. Esse é o princípio generalizável para os próximos casos. (STRECK, 2011, p. 574-575, grifo nosso).

O cidadão tem sempre o direito fundamental de obter uma resposta adequada à Constituição, que não é a única e nem a melhor, mas dá resposta adequada à Constituição. Esse direito fundamental deverá ser o guia às respostas elaboradas pelo Poder Judiciário. É dele que se está falando neste artigo. É óbvio que os juízes, por serem seres humanos, possuem convicções pessoais, crenças e ideologias, mas suas decisões não podem se justificar somente nisso, eis que os juízes precisam fundamentar suas decisões demonstrando que a decisão ocorreu com base em argumentos de princípio, e não de política, de moral ou de convicções pessoais. Haverá coerência se os mesmos princípios que foram aplicados nas decisões o serão para os casos idênticos. Há uma amálgama historicamente formada em cada sistema jurídico nacional, presente na Constituição Federal, que deverá conduzir o processo judicial de construção no Direito. Aí sim estará assegurada a integridade do Direito. A ferramenta para se conseguir atingir esse objetivo poderá ser o diálogo entre as fontes do Direito, que têm no centro dois filtros: o controle de constitucionalidade e o controle de convencionalidade, como se verá mais adiante.

No panorama assim desenhado, não há lugar para a dicotomia entre os "casos fáceis" e os "casos difíceis". Não há um método para uma categoria que seja diferente para resolver os casos categorizados na outra categoria. Conforme Dworkin (2014, p. 423-424):

Hércules não precisa de um método para os casos difíceis e outro para os fáceis. Seu método aplica-se igualmente bem a casos fáceis; uma vez, porém, que as respostas às perguntas que coloca são então evidentes, ou pelo menos parecem sê-lo, não sabemos absolutamente se há alguma teoria em operação. Incluímos entre os casos fáceis a questão de saber se, legalmente, alguém pode dirigir mais rápido que o limite de velocidade estipulado porque admitimos de imediato que nenhuma análise dos documentos jurídicos que negasse esse paradigma seria adequada. Contudo, uma pessoa cujas convicções sobre justiça e equidade fossem muito diferentes das nossas poderia não achar essa pergunta tão fácil; mesmo que terminasse por concordar com nossa resposta, insistiria em dizer que estávamos errados por ser tão confiantes. Isso explica por que questões consideradas fáceis durante um certo período tornam-se difíceis antes de se tornarem novamente fáceis - com as respostas opostas.

Classificar um caso como "fácil" ou "difícil" não é tão simples, e ao se pretender fazê-lo, poderá ocorrer muitos equívocos, em condições de esconder as efetivas características do caso con- 
creto. Esse é um risco que não se pode correr. Todos os casos deverão receber uma resposta alinhada à Constituição. Esse é o princípio.

Ost (1993, p. 80, grifo do autor), ao estudar o Juiz Hércules perspectivado por Dworkin, menciona:

[...] Dworkin estabelece uma via para a tarefa do juiz, que é a do juiz racional que "leva os direitos a sério", que domina o "império do direito", que não se esquiva da tarefa de encontrar uma solução para todos os casos, mesmo os mais difíceis. Ele deve sempre buscar a unidade do direito, e fortalecê-la em cada um de seus juízos, por meio de uma coerência narrativa que melhor se adapta ao estado passado e presente do direito, e que estabeleça a melhor hierarquia dos princípios da moral política compartilhados pela comunidade em cada momento da história.

Aqui se verifica a caracterização de um juiz alojado no interior de um sistema jurídico democrático. Ele não "inventa" o Direito, opera a sua criação, o seu desvelamento, no conjunto do chamado "império do Direito", que não é um monopólio legislativo, mas um plural de fontes e formas de possibilidades jurídicas, não disponíveis à mera escolha individual ou relativizada do tipo "qualquer uma serve". Pelo contrário, a escolha e a sua aplicação deverão ser mediadas pelos dois filtros anteriormente referidos.

\section{A constitucionalização do direito e a operatividade dos princípios: caminhos e descaminhos de sua compreensão no Brasil}

A resposta jurisdicional construída para o caso Riggs vs. Palmer mostrou a importância da participação constitucionalmente comprometida dos magistrados. Independentemente da existência ou não de uma regra expressa, que seja "perfeitamente" aplicável ao caso concreto, ou seja, aquilo que se poderia denominar de "caso fácil", a intervenção judicial nos casos da vida deverá ser norteada por princípios estruturantes do Estado e vinculados à Constituição Federal. No caso deste artigo, acrescenta-se mais um elemento, a necessidade de observância das estruturas relativas aos Direitos Humanos. Não se tem um efetivo Estado Democrático de Direito sem essas redes, barreiras ou filtros de qualidade da produção jurídica.

A importância do texto da Constituição Federal nunca foi duvidada. No entanto, a sua localização no sistema jurídico - se no topo dele ou no seu centro - ainda é objeto de discussão. Ao mesmo tempo, recentemente se tem apresentado o chamado movimento de "constitucionalização do Direito Privado", que seria mais correto denominar de "constitucionalização do Direito". Segundo Guastini (2003, p. 49, grifo do autor), a "constitucionalização dos direitos" corresponde a uma espécie de "transformação de um ordenamento jurídico totalmente impregnado pelas normas constitucionais." Não parece que deva ser algo novo, pois a Constituição sempre representou o conjunto legal como guia para o restante do ordenamento jurídico de uma sociedade, independentemente de ser do 
Direito Privado ou do Direito Público. A constitucionalização do sistema jurídico poderá ser constatada em diferentes graduações e se constata a partir do cumprimento de determinadas condições. ${ }^{9}$

A Constitucionalização do Direito colocou no centro dos sistemas jurídicos contemporâneos as Constituições que, contendo princípios e regulações de variados ramos, devem ser interpretadas evolutivamente de acordo com o modificar-se dos valores ético-políticos no bojo da comunidade a que se refere. Nesse mesmo sentido, a Constituição Federal de 1988 deve ser lida, em várias de suas normas (aqui compreendendo as regras e os princípios), ${ }^{10}$ de acordo com um perfil solidarista, na busca por mecanismos capazes de suprir as necessidades dos cidadãos.

Tem-se que a Constitucionalização do Direito trouxe a preocupação de que o Direito deve se ocupar com a construção de uma sociedade justa e solidária, cujo desafio é fazer com que o Direito não fique indiferente às injustiças sociais. Assim, Streck (2010, p. 200) afirma não haver dúvida de que o novo constitucionalismo é sinônimo de novo paradigma, em que o Direito deixa de ser meramente regulador para assumir uma feição de transformação das relações sociais.

No cenário jurídico brasileiro o fenômeno constitucionalizante somente passa a ser internalizado no ordenamento por meio da Constituição Federal de 1988 e acabou por tratar diretamente de alguns aspectos de vários ramos do Direito infraconstitucional.

Ao se adicionarem na Constituição temas que antes eram tratados apenas pelos estatutos privados, surgiram transformações especialmente, mas não exclusivamente, no sistema do Direito Civil clássico, com uma adaptação à nova realidade econômico-social, que fez com que o intérprete do Direito fosse obrigado a rever os valores ideologicamente consagrados no ordenamento jurídico e as influências interdisciplinares sofridas por ele nessa mutação.

Assim, é nessa nova realidade que Nalin (2008, p. 30) identifica um dos grandes problemas a serem superados pelo sistema jurídico brasileiro: a ruptura entre uma sociedade brasileira pós-industrial desse início de século XXI e um sistema civil codificado que, originalmente, vinculava-se a uma família nucleada no casamento, ao direito proprietário absoluto do indivíduo e ao contrato, cuja descrição econômica não supera a da histórica da circulação de riquezas.

A superação desse problema vem representada pelo fenômeno da constitucionalização do direito privado, ${ }^{11}$ não mais se limitando o legislador à disciplina das relações patrimoniais. Seguindo

\footnotetext{
9 "El concepto de constitucionalización, como yo lo entiendo, no es un concepto bipolar (verdadero o falso), de forma que un ordenamiento únicamente pueda estar constitucionalizado o no estarlo en absoluto, sin algún punto intermedio. Más bien sostengo que la constitucionalización es una cuestión de grado, en el sentido de que un ordenamiento puede estar más o menos constitucionalizado. Y esto depende de cuántas y cuáles condiciones de constitucionalización estén satisfechas en el seno de aquel ordenamento. [...] Son condiciones de constitucionalización: a) la existencia de una Constitución rígida; b) la garantía jurisdiccional de la Constitución; c) la fuerza vinculante de la Constitución; d) la sobreinterpretación de la Constitución; e) la aplicación directa de las normas constitucionales; f) la interpretación de las leyes de acuerdo a la Constitución; g) la influencia de la Constitución sobre las relaciones políticas." (GUASTINI, 2003 , p. 50 e ss.). 10 Adota-se, aqui, a proposta de Alexy (1993b), no sentido das regras como "mandados definitivos" e os princípios como "mandados de otimização". Sendo a "norma jurídica" um gênero que contempla duas espécies: as regras e os princípios.

11 Conforme Tepedino (2008, p. 22), trata-se, em uma palavra, de estabelecer novos parâmetros para a definição da ordem pública, relendo o Direito Civil à luz da Constituição, de maneira a privilegiar, insista-se ainda uma vez, os valores não patrimoniais e, em particular, a dignidade da pessoa humana, o desenvolvimento da sua personalidade, os direitos sociais e a justiça distributiva, para cujo atendimento deve se voltar a iniciativa econômica privada e as situações jurídicas patrimoniais.
} 
o Texto Constitucional, o qual impõe deveres extrapatrimoniais nas relações privadas, tendentes à realização da personalidade e da tutela da dignidade da pessoa humana, o legislador cada vez mais condiciona a proteção de situações tradicionalmente disciplinadas sob a ótica exclusivamente patrimonial ao cumprimento de deveres não patrimoniais. Aqui se revelam dois vetores de conteúdo que orientarão o movimento do círculo hermenêutico para aplicação dos princípios constitucionais, especialmente o destacado direito a uma resposta jurisdicional adequada à Constituição.

Nesse sentido, Nalin (2008, p. 34 e ss.) dispõe sete premissas metodológicas para se compreender a constitucionalização do Direito Civil:

a) a compreensão dessa nova metodologia está na própria regra jurídica, em sentido mais amplo, passando a técnica legislativa do tipo hermético (preceito e sanção) às cláusulas gerais, abrangentes e abertas;

b) a redução do contexto técnico da linguagem empregada nos textos legais, objetivando, assim, promover um atendimento às especificidades dos setores destinatários da regra elaborada, como a informática e a economia, gerando o comprometimento legislativo com uma linguagem que se distancie do apuro técnico e específico do Código Civil; implica maior eficácia das regras constitucionais e infraconstitucionais, realizando-se o comando constitucional do Estado Democrático de Direito a partir da funcionalização da linguagem técnico-jurídica;

c) a regra constitucional, enquanto vocacionada à programação das atividades do Estado e ao encaminhamento de um comportamento social desejado, está vinculada a uma função promocional do Direito, o que não se configurava no Código Civil de 1916, uma vez que seu texto "é fruto do movimento codificador, em que tal estrutura normativa ainda não era concebida, detectando-se verdadeiro hiato, nesta passagem, entre a nova vocação constitucional e o revogado Código Civil." (NALIN, 2008, p. 35);

d) a tendência de se condicionar a efetividade dos direitos patrimoniais dos atos jurídicos à realização de valores superiores do ordenamento, como a dignidade da pessoa humana, eis que valor jurídico, e outros, encontra-se no vértice da estrutura legal;

e) a necessária compreensão de um novo olhar para as fontes do Direito e a reafirmação da prevalência da Constituição em face do Código Civil;

f) o contratualismo "que revela a fórmula pela qual a sociedade exterioriza os seus interesses sociopolíticos por intermédio da negociação legislativa." Aqui entra a abertura para o manejo do diálogo entre as fontes do Direito. Não se trata mais de uma fonte, o Código Civil, mas de um leque de fontes que poderão ser conjugadas para a formatação da adequada proteção jurídica pretendida pelas partes;

g) a possibilidade de aplicação direta das normas constitucionais às relações interprivadas, na medida do reconhecimento de um ordenamento jurídico unitário e da norma- 
tiva constitucional como regra de conduta, posta no sentido da funcionalização dos institutos jurídicos preexistentes e abertos às novas tendências sociais.

Como revela Fachin (2013, p. 11), a Constitucionalização do Direito, especificamente na intensidade em que ocorreu na segunda metade do século passado, enfatiza a lacuna de travessias que clama por respostas urgentes, quer por intermédio do sistema legal quer por meio de políticas públicas. No sistema legal, uma dessas formas foi pavimentada pela presença normativa dos princípios constitucionais, especialmente o da dignidade humana. Suas funções foram exponencialmente reforçadas pela crescente complexidade das relações humanas.

Esse é o momento vivido pelo Direito brasileiro, em que de um lado se encontra uma sociedade carente da realização de direitos, e de outro, uma Constituição Federal que garante esses direitos da forma mais ampla possível. Eis o contraponto do Estado Democrático de Direito em que a lei passa a ser um instrumento de ação concreta do Estado, tendo como método assecuratório de sua efetividade a promoção de determinadas ações pretendidas pela ordem jurídica. Isso, porém, ainda não foi perfeitamente assimilado pelos juristas (STRECK, 2008, p. 47).

A configuração do movimento da chamada constitucionalização do Direito, ou melhor, do Direito Privado, não tem uma aceitação integral na doutrina. Como já mencionado, a incorporação das regras e dos princípios inseridos na Constituição sempre deveriam estar no coração do Direito, considerado um sistema ou ordenamento jurídico. ${ }^{12}$ Esse cenário pode ser especificado a partir das seguintes características:

(a) o Direito Constitucional foi arrastado para dentro do rodamoinho de disputas privadas de relevância duvidosa, com todos os desagradáveis inconvenientes para si e para a Constituição, como o barateamento da dignidade e da importância das normas constitucionais, que se veem citadas em pequenos conflitos individuais, como a cobrança de uma dívida ou a definição dos danos pelo abalroamento de automóveis. Com isso, põe-se a perder a "identidade do Direito Privado", forjada por sua antiga e respeitável história;

(b) a existência de conceitos jurídicos indeterminados e cláusulas gerais na Constituição, o que é esperável dada sua natureza normativa específica, é campo fértil para a ação dos interessados no arbítrio e no abuso da discricionariedade judicial. Se foi possível realizar demagogia judiciária com base em elementos do próprio Direito Civil, agora isso é feito com a invocação do texto constitucional. Além disso, tem-se a abertura para o que se poderia chamar metaforicamente de "toque de Midas constitucional", que é a conversão substancial de matérias eminentemente privadas em matérias constitucionais, como mero exercício de poder do Tribunal Constitucional de controle da jurisdição ordinária. (RODRIGUES JÚNIOR, 2010, p. 59).

\footnotetext{
12 O uso a expressão constitucionalização não é bem aceito por juristas atuantes no Direito Civil, sendo lugar comum a afirmativa de que todo direito é constitucional, seja ele civil, penal, tributário, do trabalho e os demais. Descrevem esses juristas que o fenômeno da constitucionalização não seria algo novo, apenas uma tentativa de reduzir a importância do Direito Civil, bem como de negar a sua tradicional construção dogmática, afirmando a utilização exagerada dos Direitos Fundamentais na interpretação das regras de Direito Civil (RODRIGUES, 2014, p. 553).
} 
O autor menciona que parte dos atritos causados pela tentativa de "colonização" do Direito Civil na Constituição ocorre em razão da permanente busca por um elemento de correção para o Direito, e assim, o recurso à Constituição pode até ser explicável, embora seu barateamento pela dogmática brasileira tenha chegado a níveis intoleráveis (RODRIGUES JÚNIOR, 2010, p. 57).

A importância da Constituição para a interpretação e o desenvolvimento (judicial) do Direito Privado é inegável. Porém, a Constituição atende a funções político-retóricas diversas daquelas da Codificação Civil (COSTA FILHO, 2014, p. 610).

Esse modelo de utilização discricionária e contra legem dos textos normativos e da Constituição dá margem a graves desvios lógicos. Invoca-se a Constituição, certos "princípios" ou "valores constitucionais" para desfazer regras de inquestionável univocidade semântica (RODRIGUES JÚNIOR, 2010, p. 30). Portanto, em nome da chamada "constitucionalização do Direito Privado" não se poderá destruir os pressupostos essenciais e estruturantes do Direito Privado. A filtragem constitucional também tem os seus limites e não poderá ser resposta para todas as questões que emergem na seara privada. A Constituição e a sua aplicação não são ilimitadas; a imersão de todas as áreas jurídicas, a fim de atenderem às regras e aos princípios inseridos na Constituição, afigura-se obrigatória, mas isso não resolve todos os problemas. Há limites.

\section{A dignidade da pessoa humana como princípio (ou regra?) qualificador(a) do diálogo entre as fontes do direito para estruturar um "modelo" à fundamentação das decisões judiciais sobre direitos fundamentais}

No interior do movimento de Constitucionalização do Direito Civil, com a necessidade de se ter certos cuidados, ${ }^{13}$ vive-se um cenário em que a dignidade da pessoa humana impõe transformações radicais na dogmática civilista, estabelecendo uma dicotomia essencial entre as relações jurídicas existenciais e as relações jurídicas patrimoniais.

\footnotetext{
13 "[...] a constitucionalização do direito civil é uma grave e recorrente ameaça à liberdade e à autonomia das relações privadas que se ampara na ideia equivocada de uma grande proximidade entre o direito civil e a Constituição. Ora, as garantias constitucionais apenas traduzem o reconhecimento estatal de uma ordem jurídico-privada, sem causar impacto em seu conteúdo. Nem mesmo o detalhado catálogo dos direitos fundamentais é capaz de criar uma ordem acabada e fechada que permita inferir a regulação civil. O primado material das relações privadas é todo do direito civil, que se distancia da constituição política e atua como um desenho da constituição social. [...] o nível reflexo da eficácia constitucional no Direito privado demanda sérias prevenções dogmáticas, na medida em que não se resume a uma mera operação jurídica de transplantação de normas públicas para relações privadas sem clivagem alguma. O recurso indiscriminado que se faz à Constituição na regulação das relações privadas é um fenômeno que em nada contribui para um modelo de efetiva relevância jurídica das normas de tutela da personalidade, constitucionais ou civis. Isto porque acaba por banalizar preceitos fundamentais, enfraquecendo a força jurídica de intervenções constitucionais que se façam verdadeiramente necessárias, sobretudo para conter posições de supremacia de poder capazes de interferir na esfera de livre vontade do indivíduo subjugado. Mas também porque tende a 'publicizar' o Direito privado, impondo aos particulares adstrições originalmente concebidas para o Estado que acabam por subtrair-lhes a autodeterminação negocial." (MAZUR, 2012, p. 32).
} 
A dignidade da pessoa humana é um dos fundamentos estruturantes do Estado Democrático de Direito, ${ }^{14}$ conforme o artigo $1^{\circ}$ da Constituição Federal de $1988 .{ }^{15}$ Desse modo, a dignidade da pessoa humana foi consagrada na CF como direito fundamental, inserto em uma regra, mas com certas características de princípio. Tem-se, portanto, um exemplo de simbiose entre a regra e o princípio, modelando as estruturas da construção do Direito. ${ }^{16} \mathrm{E}$, assim, o princípio da dignidade da pessoa humana não diz apenas respeito ao privado ou ao público, porquanto seja um ponto de conexão entre os dois.

Sarlet (2001, p. 60), conceituando dignidade, menciona que:

É a qualidade intrínseca e distintiva de cada ser humano que o faz merecedor do mesmo respeito e consideração por parte do Estado e da comunidade, implicando, neste sentido, um complexo de direitos e deveres fundamentais que assegurem a pessoa tanto contra todo e qualquer ato de cunho degradante e desumano, como venham a lhe garantir as condições existenciais mínimas para uma vida saudável, além de propiciar e promover sua participação ativa e co-responsável nos destinos da própria existência e da vida em comunhão com os demais seres humanos.

No âmbito da Filosofia, não há como negar que uma conceituação clara do que é efetivamente a dignidade da pessoa humana, inclusive para efeitos de definição do seu âmbito de proteção como norma jurídica fundamental, revela-se no mínimo difícil e complexa de ser obtida, pois, como ressalta Sarlet (2009b, p. 18), tal dificuldade decorre certamente da circunstância de que se cuida de um conceito de contornos vagos e imprecisos. De qualquer sorte, tem-se que a dignidade é algo real, vivenciado concretamente por cada ser humano.

Esse princípio, portanto, busca garantir o respeito e a proteção não apenas no sentido de se assegurar um tratamento humano e não degradante, mas, também, a proteção da integridade psicofísica do ser humano. Significa a ruptura com um modelo que enxergava em valores individualistas o seu fundamento axiológico. Assim, o valor dignidade atinge todos os setores da ordem jurídica, o que desvela a grande dificuldade em se delimitar os contornos hermenêuticos que esse princípio detém, correndo-se o risco de atribuir-lhe apenas um sentido abstrato que impossibilite ainda mais a sua aplicação, quando o desejo é justamente o contrário.

\footnotetext{
14 Quanto ao conceito de Estado Democrático de Direito, considerando os fins e os limites deste artigo, adota-se: "o Estado Democrático de Direito é o novo modelo que remete a um tipo de estado em que se pretende precisamente a transformação em profundidade do modo de produção capitalista e sua substituição progressiva por uma organização social de características flexivelmente sociais, para dar passagem, por vias pacíficas e de liberdade formal e real, a uma sociedade onde se possam implementar superiores níveis reais de igualdades e liberdades." (STRECK, 2001, p. 40). "[...] quando assume o feitio democrático, o Estado de Direito tem como objetivo a igualdade e, assim, não lhe basta limitação ou a promoção da atuação estatal, mas referenda a pretensão à transformação do status quo. A lei aparece como instrumento de transformação da sociedade não estando mais atrelada inelutavelmente à sanção ou à promoção. $O$ fim a que pretende é a constante reestruturação das próprias relações sociais." (STRECK; MORAIS, 2013, p. 114).

15 Constituição Federal: Artigo $1^{\circ}$ A República Federativa do Brasil, formada pela união indissolúvel dos Estados e Municípios e do Distrito Federal, constitui-se em Estado Democrático de Direito e tem como fundamentos:

$[\ldots]$

III - a dignidade da pessoa humana;

$[\ldots]$

16 Sarlet (2013, p. 125-126) concorda com essa dupla categorização da dignidade da pessoa humana.
} 
É como leciona Sarlet (2009a, p. 103), ao afirmar que uma das funções exercidas pelo princípio fundamental da dignidade da pessoa humana reside no fato de ser, simultaneamente, elemento que confere unidade de sentido e legitimidade a uma determinada ordem constitucional, constituindo-se no ponto de Arquimedes do Direito Constitucional, e, embora plenamente reconhecido, há de ser exaustivamente enfatizado.

Essa concepção permite inferir que a Constituição Federal de 1988 galgou a dignidade da pessoa humana à condição de fundamento do Estado Democrático de Direito, podendo ser considerada uma Carta Política comprometida com a realização da pessoa humana, embora nem sempre esse compromisso se desvele em ações, na realidade. E, nesse sentido, serve como um referencial na hierarquização axiológica inerente ao processo de criação e desenvolvimento jurisprudencial do Direito (SARLET, 2009b, p. 106).

Portanto, a dignidade da pessoa humana, deve prevalecer como princípio supremo da ordem constitucional (SARLET, 2006, p. 112); é mais que um direito fundamental, é a razão de existir do próprio Estado e do Direito, o guia de toda a Constituição, e projeta-se sobre todo o ordenamento jurídico pátrio.

A primazia da proteção da pessoa humana como cláusula geral de tutela está inserida no sistema jurídico nacional. Assim, a vulnerabilidade da pessoa humana deve ser considerada, e o princípio da proteção da dignidade humana deve ser concretizado, fazendo-se presente sempre que necessário. É uma espécie de fiscal, sempre presente e atento para garantir o seu próprio respeito nos casos da vida.

Vale expor que a dignidade humana não é uma criação dada pela Constituição Federal, muito embora seja por ela tutelada. A Constituição apenas atribuiu-lhe "o valor supremo de alicerce da ordem jurídica democrática", como descreve Moraes (2003, p. 83), passando o referido valor a fazer parte definitivamente de todas as relações jurídicas existentes em nosso País.

Dessa forma, a concepção do Direito Privado Constitucional passa a se apresentar com os seguintes elementos nucleares: "com base em concepção principiológica e menos normativa, demonstra os novos rumos do Direito Privado e o destaque dado à pessoa e sua dignidade, como o elemento nuclear da relação jurídica." (LISBOA, 2010, p. 45).

Apesar dessas "conquistas", a dignidade da pessoa humana corre risco de esvaziamento, quando é utilizada para fundamentar qualquer pleito:

[...] A Dignidade da pessoa humana acabou por ganhar, assim, a propriedade de servir a tudo. De ser usada onde cabe com acerto pleno, onde convém com adequação discutível e onde definitivamente não é o seu lugar. Empobreceu-se. Esvaziou-se. Tornou-se um tropo oratório que tende à flacidez absoluta. Alguém acha que deve ter melhores salários? Pois que se elevem: uma simples questão de dignidade da pessoa humana. Faltam às estradas condições ideais de tráfego? É a própria dignidade da pessoa humana que exige sua melhoria. $O$ semáforo desregulou-se em consequência de chuvas inesperadas? Ora, substituam-no imediatamente. A dignidade da pessoa humana não pode esperar. É ela própria, a dignidade da pessoa humana, que se vê lesada quando a circulação viária das cidades não 
funciona impecavelmente 24 horas por dia. $O$ inquilino se atrasou com os alugueres? Despejem-no o quanto antes: Fere a dignidade da pessoa humana ver-se o locador privado, ainda que por um só dia, dos direitos que a locação lhe assegura. (VILLELA, 2009, p. 562).

Aí se têm algumas situações da vida, importantes e impactantes, sem dúvida, mas nem todas poderão e nem deverão ser decididas sob o fundamento da dignidade da pessoa humana. Se tudo tem fundamento na dignidade da pessoa humana, nada tem. E isso é perigoso, pois se esvazia o seu conteúdo prático para aquelas situações efetivamente violadoras da dignidade da pessoa humana. Não se poderá banalizar a sua utilização. Há limites que deverão ser vislumbrados com muita cautela. No manuseio do diálogo entre as fontes do Direito se poderá vislumbrar o filtro do controle de constitucionalidade e do controle da convencionalidade, como um modelo para priorizar as situações da vida que merecerão o amparo em decorrência da dignidade da pessoa humana.

Ao examinar a jurisprudência, o quadro não é mais animador, pelo contrário, gera mais preocupação. A prova disso são dados empíricos coletados apenas na Revista dos Tribunais, no período entre 1995 e 2010, em que se encontraram 217 acórdãos nos quais a expressão dignidade humana é encontrada como fundamento da decisão adotada. $O$ objeto desses julgados é também muito diversificado: saúde; relações de trabalho; habeas corpus; mensuração da pena; liberdade; direitos fundamentais; ordem pública; descumprimento de preceito fundamental; jurisdição e competência; violência contra a mulher; prisão preventiva; e ampla defesa e contraditório (RODRIGUES JÚNIOR, 2010, p. 42). Ainda sobre esse tema, por vezes, tem-se a concessão de medicamentos para garantir a dignidade da pessoa humana e tem-se, no mesmo Tribunal, decisões que negam pedidos de medicamentos para garantir a dignidade da pessoa humana (WEBBER, 2013). Sarlet (2013, p. 123-125), ao comentar o artigo $1^{\circ}$, III, da Constituição do Brasil, também elenca uma grande diversidade de situações em que especialmente o Supremo Tribunal Federal e o Superior Tribunal de Justiça invocam a dignidade da pessoa humana, destacando-se: tortura perpetrada contra adolescentes por parte de policiais militares; impossibilidade de se compelir o suposto pai a realizar o exame de DNA; bloqueio de recursos públicos para o atendimento à saúde e à educação; possibilidade de controle judicial de políticas públicas quando se cuidar especialmente da implementação da garantia do mínimo existencial; proteção às condições mínimas de vida; corte de água ou energia elétrica; e imprescritibilidade dos crimes de tortura e perseguição política durante o Regime Militar.

Assim, resta demonstrado como a dignidade da pessoa humana vem sendo utilizada das mais diferentes formas em decisões judiciais, sem maiores fundamentações, a partir do senso comum teórico, "desvirtuando" a ideia central desse princípio que é um dos alicerces da ordem jurídica democrática. Uma decisão judicial fundada na dignidade da pessoa humana não estará configurada pela simples invocação dela. É preciso justificar, ponderar e ligar a sua aplicação à utilização judicial anterior em caso semelhante. Essa é a lição que se deve trazer para o Direito brasileiro a partir do julgamento do caso Riggs vs. Palmer. Não copiar, mas aprender com o modo responsável e compro- 
metido da criação judicial do Direito. Não poderá ser considerada fundamentada uma decisão que simplesmente se "funda na consciência do julgador", como se pode verificar no seguinte trecho:

Não me importa o que pensam os doutrinadores. Enquanto for ministro do Superior Tribunal de Justiça, assumo a autoridade da minha jurisdição. $O$ pensamento daqueles que não são ministros deste Tribunal importa como orientação. A eles, porém, não me submeto. Interessa conhecer a doutrina de Barbosa Moreira ou Athos Carneiro. Decido, porém, conforme minha consciência. Precisamos estabelecer nossa autonomia intelectual, para que este tribunal seja respeitado. É preciso consolidar o entendimento de que os Srs. Ministros Francisco Peçanha Martins e Humberto Gomes de Barros decidem assim, porque pensam assim. E o Superior Tribunal de Justiça decide assim porque a maioria de seus integrantes pensa como estes ministros. Esse é o pensamento do Superior Tribunal de Justiça, e a doutrina que se amolde a ele. É fundamental expressarmos o que somos. Ninguém nos dá lições. Não somos aprendizes de ninguém. Quando viemos para este Tribunal, corajosamente assumimos a declaração de que temos notável saber jurídico - uma imposição da Constituição Federal. Pode não ser verdade. Em relação a mim, certamente não é, mas, para efeitos constitucionais, minha investidura obriga-me a pensar que assim seja. (BRASIL, 2003, p. 216).

Verifica-se um forte contraste entre esse trecho de uma "decisão judicial" brasileira e a argumentação construída para fundamentar a decisão no caso Riggs vs. Palmer. É aí que se posiciona o conteúdo deste artigo, ao defender a necessidade de fundamentação da decisão judicial como um direito fundamental. E isso independe do Sistema Jurídico ao qual o Poder Judiciário pertence. A construção jurisprudencial do Direito deverá ser encorada em variadas fontes, principalmente na produção científica desenvolvida pela Doutrina. Quer dizer: não aquela que simplesmente repete o conteúdo da lei ou de decisões judiciais, mas a Doutrina (com letra maiúscula) produzida no cenário de investigação desenvolvida nos Programas de Pós-Graduação em Direito, que desenvolvem pesquisas jurídicas avançadas. Adotam-se aqui os predicativos desenvolvidos sobre a Doutrina, conforme apresentado por Martins-Costa (2014, p. 9 e ss.): a Doutrina interpreta; também cria modelos que são elaborados pela ressignificação de uma solução não originalmente disposta à situação em causa ou pelo "transpasse", "desde que não acrítico nem anacrônico, de soluções formuladas em outros campos semânticos, como a economia, o direito comparado; ou pela recuperação de figuras que estiverem em desuso ou, finalmente, pela criação ex novo, então plasmando figuras originais." (MARTINS COSTA, 2014, p. 27-28, grifo do autor).

É essa Doutrina que se entende neste artigo e que se coloca como uma verdadeira fonte de Direito na estruturação do diálogo entre as fontes do Direito. Por outro lado, não se consideram verdadeira doutrina as meras trivialidades das opiniões emitidas, com o caráter meramente descritivo, parafraseando a lei, ou a recortar, copiar e colar decisões judiciais reprodutoras dessa mesma doutrina, em um círculo vicioso que nada constrói (MARTINS COSTA, 2014, p. 22). Reafirmado o papel que a Doutrina deverá ocupar no conjunto das fontes do Direito, propõe-se o Esquema 1 sobre o modelo de diálogo entre as fontes do Direito: ${ }^{17}$

17 Estudos relativos ao diálogo entre as fontes do Direito podem ser consultados em: Engelmann (2012, p. 319-344). 
Esquema 1 - Modelo de diálogo entre as fontes de Direito

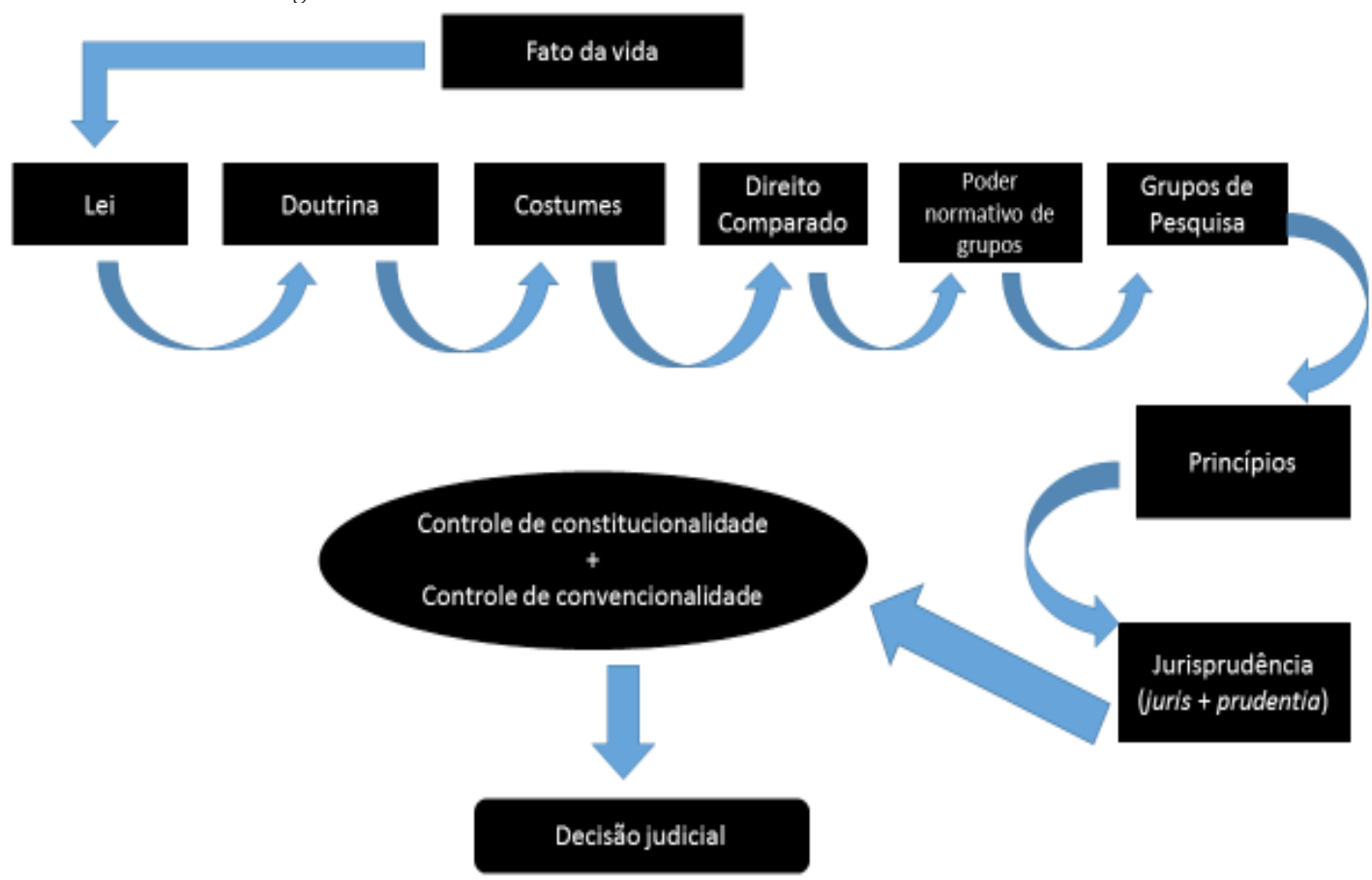

Fonte: os autores.

O que se tem nesse Esquema é o modelo de diálogo entre as fontes do Direito, sem a primazia de nenhuma das manifestações do jurídico, mas em uma paridade. Busca-se aferir as contribuições de cada uma das fontes, a fim de se encontrar aquela que possa juridicizar da melhor forma possível - o que equivale a atender integralmente as características estruturantes da dignidade da pessoa humana, atento à integralidade do conteúdo da Constituição do Brasil (controle de constitucionalidade) e dos documentos relativos aos Direitos Humanos, participando do controle de convencionalidade (destacadamente: Convenção Americana de Direitos Humanos e Declaração Universal dos Direitos Humanos - sem a exclusão dos demais textos sobre a matéria - e as decisões proferidas pelas Cortes Regionais e Universal dos Direitos Humanos).

No movimento do diálogo, busca-se respeitar as particularidades de cada caso concreto, as contribuições dos textos legais específicos - aqui atentos, por exemplo, ao cumprimento do estatuído pelo Código Civil e dos demais "códigos" elaborados nos diversos microssistemas do Direito Privado - aos ensinamentos apontados pela Doutrina, com as características estudadas, e a produção jurisprudencial do Direito, entendendo-se essa última apenas como as decisões fundamentadas e que evidenciem a prática da phrónesis aristotélica. Para essa configuração, será preciso organizar o modo de ser e agir a partir da chamada "razão prática", ou seja, um raciocínio que não planeja respostas exatas para todas as situações. Pelo contrário, a procura deve ser sempre por uma resposta adequada para aquele caso concreto. Serão fundamentais, portanto, a experiência e a inteligência, que repre- 
sentam a expressão da sabedoria prática, presente na pessoa prudente (o phrónimos, de Aristóteles). A experiência que é adquirida pela vivência das situações, ou seja, sempre se aprende algo no enfrentamento de um caso da vida. Esse aprendizado exige uma determinada inteligência, que nada mais é do que a capacidade pessoal para avaliar, tomar as decisões e guardar as respostas - sejam acertos, sejam erros. É assim que Aristóteles descreve o phrónimos, aquele que tem prudência: "[...] Pensa-se que é característico de uma pessoa que tenha phrónesis ser capaz de deliberar bem acerca do que é bom e convincente para si mesma, não em relação a um aspecto particular e sim acerca das espécies de coisas que nos levam a viver bem de um modo geral." (ARISTÓTELES, 2001, 1140a). Aqui está a caracterização de qualquer jurista. Além do mais, o magistrado, em qualquer grau de jurisdição, deverá preencher os descritos elementos para que a sua decisão possa ser considerada jurisprudência, como fonte do Direito. A construção da resposta jurídica exige uma espécie de colaboração, ou uma rede colaborativa, em condições de enlaçar a decisão atual com aquelas já tomadas - sobre tema semelhante - por seus antecessores. Não poderá haver quebra da tradição sem que se tenha efetivamente uma razão grave que a justifique. Não há lugar no movimento do diálogo entre as fontes para decisões lastreadas em subjetivismos e pessoalismos. Isso não será Direito. Portanto, a lição do caso Riggs vs. Palmer sinaliza este caminho: os Direitos Fundamentais em geral exigem uma decisão judicial que tenha os referidos pressupostos, seja de quem emite a decisão, seja sobre o seu conteúdo. E mais, decidir significa sempre escolher ponderadamente, mais do que em nenhum momento, as lições de Robert Alexy, destacadamente sobre a regra da ponderação - que se deverá manejar no movimento do diálogo entre as fontes do Direito e sendo o pressuposto para gerir os resultados do círculo hermenêutico.

A regra da ponderação, permeada pela aplicação integral dos três níveis da proporcionalidade (adequação, necessidade e proporcionalidade em sentido estrito) permitirá a prática das chamadas condições de prioridade (ALEXY, 1993a) que indicará a regra e/ou o princípio e/ou uma das demais fontes aplicáveis na fundamentação da resolução do caso da vida, mirando-se no horizonte hermenêutico da interpretação construtiva ou colaborativa (DWORKIN, 2011). A regra da ponderação é uma deliberação, uma regra de escolha, em que a phrónesis, de Aristóteles, apresenta-se como qualificadora da escolha a ser empreendida em relação aos casos da vida humana, que sempre são contingentes, conforme destaca Aubenque (2003, p. 70), ao estudar a prudência aristotélica: "[...] o prudente não é, enquanto tal, nem sábio, nem sapiente: não sendo dotado de nenhuma familiaridade especial com o transcendente, move-se no nível do particular e fixa a cada um o justo meio que corresponde a sua particularidade." Qualquer um que queira participar do processo de criação do jurídico deverá se mover nessa caracterização. A Regra de ponderação, em Alexy (1997, p. 171), estabelece: "quanto maior seja o grau de não realização ou de menosprezo de um princípio, tanto maior deve ser a importância da satisfação do outro." Portanto, prudente, phrónimos, é aquele que consegue vislumbrar, entender e aplicar a regra da ponderação ampliada: "quanto maior seja o grau de justificação para a não utilização hermenêutica de uma das fontes do 
Direito, tanto maior deverá ser a contribuição de outra fonte do Direito para a resolução adequada do caso da vida." Se essa "regra" for bem assimilada e praticada, estarão assegurados o controle de constitucionalidade e o controle de convencionalidade.

\section{Conclusão}

A especificação das fontes do Direito e a sua aplicação nos casos concretos da vida representam dois desafios para a área do conhecimento humano chamado de Direito. $\bigcirc$ positivismo jurídico (ALEXY, 2015), considerando variadas matizes de manifestação, tem-se se caracterizado pela defesa da aplicação da lei como a mais importante ou a única fonte do Direito. Essa postura limita a fundamentação das decisões jurídicas, pois a lei sempre representa uma fotografia do passado, definida a partir do presente, lançando uma projeção do comportamento humano para o futuro.

A vida humana tem se modificado com uma velocidade cada vez maior, desafiando o procedimento adotado para a elaboração da lei. A dinamicidade das relações humanas exige, na mesma velocidade, possibilidades plurais para a estruturação das respostas jurídicas exigidas. Cada vez mais, ao lado da criatividade na produção do jurídico, serão exigidas alternativas de expressão do Direito que tenham velocidade e flexibilidade para se adequar aos novos movimentos da vida na sociedade.

A Constituição ocupa um lugar fundamental de justificação das respostas produzidas, no movimento do diálogo entre as fontes do Direito, manejado por pessoas que reúnam as características do phrónimos aristotélico. A própria Constituição, assim como os textos relativos aos Direitos Humanos, tem uma dinamicidade peculiar:

[...] O fundamento no Direito não é algo a descobrir, mas algo que está por construir. Fundamentar a Constituição é imaginá-la, e a imaginação não descansa. [...] A Constituição não é um ponto fixo para o Direito. [...] A Constituição não reafirma o Direito, mas o surpreende e o encontra inadaptado. [...] Como horizonte do pensamento jurídico, a Constituição não encerra nenhuma plenitude, não representa a totalidade dos consensos possíveis. Seus princípios não são identidades, mas diferenças, formas e limites que a separam de um espaço exterior não marcado, que sempre a estão distinguindo. (MARTINEZ GARCIA, 1999, p. 187-188, 201).

Este é o ponto: a Constituição, e a partir dela todas as fontes do Direito, não são estruturas paralisadas e prontas para serem aplicadas. Elas todas estão em movimento. Por isso, a representação do modelo do diálogo entre as fontes do Direito, em que se pode vislumbrar as idas e vindas das diversas fontes, em um movimento circular, mas que poderá assumir outras formas de movimento, sempre perspectivado para o atendimento mais adequado possível das questões suscitadas pelo caso da vida. Por isso a formulação da regra de ponderação ampliada, que estrutura as pontes ou os elos entre as fontes, orientadas pelos princípios constitucionais, destacadamente pela dignidade da pessoa humana. 
Nesse movimento também se deverá construir e perceber as limitações da constitucionalização do Direito Privado. Observar os limites significa dizer: há relações privadas que ainda deverão ser solucionadas por meio da aplicação do Código Civil e de outros Códigos forjados nos microssistemas privados. A Constituição é coadjuvante nesses casos. Ela não resolve tudo e nem se poderá aplicá-la para solver qualquer situação. Resta ainda mais clara essa situação dos limites, quando se busca a iluminação trazida pelo manejo do controle de convencionalidade, ainda pouco conhecido pela Doutrina no Brasil.

O caso Riggs vs. Palmer foi trazido para o cenário deste artigo a fim de mostrar que a construção de respostas jurídicas sempre deverá ser ancorada na história e tradição do horizonte conformado daquela situação, em casos anteriores. Os princípios também reforçam essa conclusão. Embora se tenha claro que os referidos princípios não sejam os princípios gerais do Direito, que se encontram (ainda) consagrados no artigo $4^{\circ}$, da Lei de Introdução às Normas do Direito Brasileiro, que estão vinculados a uma tradição positivista. Não se faz a crítica dessa categoria de princípios, considerando que eles representaram um avanço no momento histórico em que foram planejados, mas que se mostram inadequados e não recepcionados pela Constituição do Brasil de 1988.

O problema que orientou a elaboração deste artigo foi assim apresentado na Introdução: sob quais condições o caso Riggs vs. Palmer poderá orientar a construção de modelo jurídico para se conservar a fundamentalidade constitucional da dignidade da pessoa humana, no panorama da chamada constitucionalização do Direito Privado? O percurso da pesquisa sinalizou que a constitucionalização do Direito Privado deverá ser examinada com cautela, sob pena de destruir as bases e os institutos próprios do Direito Privado, em nome de uma constitucionalização sem limites e critérios, colocando em risco as características jurídicas que distinguem o Direito Público do Direito Privado. O movimento da invasão da Constituição em todos os ramos do Direito e a incorporação de muitos institutos do Direito Privado nas regras constitucionais passou a (falsa) impressão de que o Código Civil e os demais textos legais tipicamente privados tivessem ficado sem função. Não é o que se deve imaginar e nem praticar. Tanto a Constituição quanto o Código Civil continuam existindo e com aplicação específica nas relações da vida. O que se exige para a percepção desse movimento e dos limites é o exercício hermenêutico realizado pelo phrónimos.

Não pode haver surpresas na resolução dos casos da vida, pois as fontes são conhecidas e deverão ser manejadas no interior do diálogo entre as fontes do Direito, com criatividade e flexibilidade para dar conta do inédito e do inovador, próprio do gênero humano. A dignidade da pessoa humana, como se viu, não poderá ser usada como um princípio (ou regra) que seja capaz de assegurar a proteção de toda e qualquer demanda oriunda da sociedade. Para tanto, as decisões judiciais no Brasil deverão ser fundamentadas adequadamente, em atenção a esse direito fundamental inserido na Constituição do Brasil, observando o horizonte hermenêutico já construído para o tema a ser decidido, na tentativa de continuar a linha decisória trazida pela tradição. Não se pensa em construir a resposta correta, mas a resposta adequada ao caso concreto. Aí o ponto fulcral que se pode apren- 
der das decisões proferidas no Sistema Jurídico da Common Law, ou seja, é uma tradição que precisa continuar. As rupturas são possíveis, mas em casos muito bem justificados. Não são a regra. $\bigcirc$ que não se verifica no Brasil. É difícil a criação de laços de tradição se cada magistrado decide como quer e de acordo com a sua consciência. Essa não é uma resposta constitucional e convencionalmente adequada. Aprender com a caminhada bem mais longa da Common Law não significa imitação ou cópia, mas humildade intelectual de observar e trazer para o cenário brasileiro, de maneira crítica e contextualizada, lições que já mostraram ser positivas. Aqui a importância fulcral do estudo do caso trazido na primeira seção do artigo.

\section{Referências}

ALEXY, Robert. Derecho y Razón Práctica. México: Distribuciones Fontamara, 1993 a.

ALEXY, Robert. El concepto y la Validez del Derecho. 2. ed. Tradução Jorge M. Seña. Barcelona: Gedisa, 1997.

ALEXY, Robert. Inclusive Non-Positivism. Espaço Jurídico Journal of Law, Joaçaba, v. 16, n. 2, p. 283292, jul./dez. 2015.

ALEXY, Robert. Teoría de los Derechos Fundamentales. Tradução Ernesto Garzón Valdéz. Madrid: Centro de Estudios Constitucionales, 1993b.

ARISTÓTELES. Ética a Nicômaco. 4. ed. Tradução Mário da Gama Kury. Brasília, DF: Ed. da UnB, 2001.

AUBEnQUE, Pierre. A Prudência em Aristóteles. Tradução Marisa Lopes. São Paulo: Discurso Editorial, 2003.

BENIGNO, Verônica. Robert Earl. Historical Society of The New York Courts. Disponível em: < http:// www.nycourts.gov/history/legal-history-new-york/history-legal-bench-court-appeals.html?http://www.nycourts.gov/history/legal-history-new-york/luminaries-court-appeals/earl-robert. html>. Acesso em: 20 jan. 2016.

BRASIL. Superior Tribunal de Justiça. AgRg nos EREsp 319.997/SC. Relator: Ministro Francisco Peçanha Martins. Relator para Acórdão: Ministro Humberto Gomes de Barros. Órgão Julgador: Primeira Seção. Julgamento em 14 ago. 2002. Diário de Justiça, 07 abr. 2003.

CASO RIGSS vs. PALMER. The Road Not Taken: Riggs and the Fiction of Civil Death. Disponivel em: <http://publishing.cdlib.org/ucpressebooks/view?docId=ft9q2nb693\&chunk.id=d0e1538\&toc. $\mathrm{id}=\mathrm{d} 0 \mathrm{e} 1282 \&$ brand $=$ ucpress;query=socialized\%20medicine $>$. Acesso em: 10 jan. 2016.

COSTA FILHO, Vesceslau Tavares. Não mencione o código de Napoleão! Análise crítica da pesquisa no ambiente das pós-graduações em Direito Civil. In: RUZYK Carlos Eduardo Pianovski et al. (Org.). Direito civil constitucional. A ressignificação da função dos institutos fundamentais do Direito civil contemporâneo e suas consequências. Florianópolis: Conceito Editorial, 2014. p. 605-612.

DWORKIN, Ronald. Justice for Hedgehogs. Cambridge: Harvard University Press, 2011. 
DWORKIN, Ronald. Levando os Direitos à Sério. Tradução Nelson Boeira. 3. ed. São Paulo: WMF Martins Fontes, 2010.

DWORKIN, Ronald. O Império do Direito. Tradução Jéferson Luiz Camargo. Revisão técnica Gildo Sá Leitão Rios. 3. ed. São Paulo: Martins Fontes, 2014.

ENGELMANN, Wilson. Crítica ao positivismo jurídico. Princípios, regras e o conceito do Direito. Porto Alegre: Sérgio Antonio Fabris, 2001.

ENGELMANN, Wilson. O diálogo entre as fontes do Direito e a gestão do risco empresarial gerado pelas nanotecnologias: construindo as bases à juridicização do risco. In: STRECK, Lenio Luiz; ROCHA, Leonel Severo; ENGELMANN, Wilson (Org.). Constituição, Sistemas Sociais e Hermenêutica: Anuário do Programa de Pós-Graduação em Direito da Unisinos. Porto Alegre: Livraria do Advogado, 2012. p. 319-344.

FACHIN, Luis Edson. Mind the gap between the new portfolio and the so-called old systems. Civilistica.com, i. 2, n. 1, 2013.

GADAMER, Hans-George. Verdade e Método. Tradução Enio Paulo Giachini. Petrópolis: Rio de Janeiro: Vozes, 2002. v. 2.

GUASTINI, Riccardo. La "constitucionalización" del ordenamiento jurídico: El caso italiano. In: CARBONELL, Miguel (Ed.). Neconstitucionalismo(s). Madrid: Editorial Trotta, 2003.

LAW RESOURCE (Org.). Bulk Access to primary Legal materials. Disponível em: <https://law. resource.org/pub/us/case/reporter/US/117/117.US.591.html>. Acesso em: 10 jan. 2016.

LIBRARY OF CONGRESS. United States: Inheritance Laws in the 19th and 20th Centuries. Disponível em: <http://www.loc.gov/law/help/inheritance-laws/unitedstates.php\#_ftnref16>. Acesso em: 20 jan. 2016.

LISBOA, Roberto Senise. Dignidade e solidariedade civil-constitucional no direito brasileiro. Revista de Direito Privado, v. 11, n. 42, p. 30-70, abr./jun. 2010.

MARTINEZ GARCIA, Jesús Ignacio. La Constitución, Fundamento Inquieto del Derecho. Revista Española de Derecho Constitucional, Madrid: Centro de Estudios Politicos y Constitucionales, n. 55, enero-abr. 1999.

MARTINS-COSTA, Judith. Autoridade e utilidade da doutrina: a construção dos modelos doutrinários. In: MARTINS-COSTA, Judith (Org.). Modelos de Direito Privado. São Paulo: Marcial Pons, 2014. p. 9-40.

MAZUR, Maurício. A dicotomia entre os direitos de personalidade e os direitos fundamentais. In: MIRANDA, Jorge; RODRIGUES JUNIOR, Otavio Luiz; FRUET, Gustavo Bonato (Org.). Direitos da personalidade. São Paulo: Atlas, 2012.

MORAES, Maria Celina Bodin de. Danos à pessoa humana. Rio de Janeiro: Renovar, 2003.

NALIN, Paulo. Do contrato: conceito pós-moderno em busca de sua formulação na perspectiva civil-constitucional. 2. ed. Curitiba: Juruá, 2008.

OST, Françóis. Júpiter, Hércules, Hermes: três modelos de juez. Doxa, n. 14, 1993. 
OWENS V. OWENS. Case text. Disponível em: <https://casetext.com/case/owens-v-owens-94>. Acesso em: 05 jan. 2016.

RODRIGUES, Francisco Luciano Lima. O fenômeno da Constitucionalização do Direito: seus efeitos sobre o Direito Civil. In: RUZYK, Carlos Eduardo Pianovski et al. (Org.). Direito civil constitucional. A ressignificação da função dos institutos fundamentais do Direito civil contemporâneo e suas consequências. Florianópolis: Conceito Editorial, 2014. p. 547-562.

RODRIGUES JÚNIOR, Otavio Luiz. Estatuto epistemológico do Direito Civil contemporâneo na tradição de Civil Law em face do neoconstitucionalismo e dos princípios. Meritum, Belo Horizonte, v. 5 , n. 2, p. 13-52, jul./dez. 2010

SARLET, Ingo Wolfgang. A Eficácia dos Direitos Fundamentais. 6. ed. rev. atual. e ampl. Porto Alegre: Livraria do Advogado, 2006.

SARLET, Ingo Wolfgang. Comentário ao artigo 1ํ III. In: CANOTILHO, José Joaquim Gomes et al. (Coord.). Comentários à Constituição do Brasil. São Paulo: Saraiva/Almedina, 2013. p. 121-128.

SARLET, Ingo Wolfgang. Dignidade da Pessoa Humana e Direitos Fundamentais na Constituição Federal de 1988. Porto Alegre: Livraria do Advogado, 2001.

SARLET, Ingo Wolfgang. Dignidade da pessoa humana e "novos" direitos na Constituição Federal de 1988: algumas aproximações. In: MARTEL, Letícia de Campos Velho (Org.). Estudos contemporâneos de direitos fundamentais. Volume II. Rio de Janeiro: Lumen Juris, 2009a.

SARLET, Ingo Wolfgang (Org.). Dimensões da dignidade: ensaios de filosofia do direito e direito constitucional. 2. ed. Porto Alegre: Livraria do Advogado, 2009b.

STRECK, Lenio Luiz; MORAIS, José Luis Bolsan de. Comentário ao artigo $1^{\circ}$. (Estado Democrático de Direito). In: CANOTILHO, José Joaquim Gomes et al. (Coord.). Comentários à Constituição do Brasil. São Paulo: Saraiva; Almedina, 2013. p. 113-116.

STRECK, Lenio Luiz. Decisionismo e discricionariedade judicial em tempos pós-positivistas: o solipsismo hermenêutico e os obstáculos à concretização da Constituição no Brasil. Separata: o direito e o futuro, o futuro do direito. Coimbra: Almedina, 2008.

STRECK, Lenio Luiz. Diálogos (neo)constitucionais. In: DUARTE, Écio Oto Ramos; POZZOLO, Susanna (Org.). Neoconstitucionalismo e positivismo jurídico: as faces da teoria do direito em tempos de interpretação moral da Constituição. 2. ed. São Paulo: Landy, 2010.

STRECK, Lenio Luiz. Hermenêutica Jurídica e (m) Crise: uma aplicação hermenêutica da construção do Direito. 3. ed. Porto Alegre: Livraria do Advogado, 2001.

STRECK, Lenio Luiz. Verdade e Consenso: Constituição, Hermenêutica e Teorias Discursivas. São Paulo: Saraiva, 2011.

TEPEDINO, Gustavo. Premissas Metodológicas para a Constitucionalização do Direito Civil. In: TEPEDINO, Gustavo (Org.). Temas de Direito Civil. 4. ed. rev. e atual. Rio de Janeiro: Renovar, 2008.

VILLELA, João Baptista. Variações impopulares sobre a dignidade da pessoa humana. In: Superior Tribunal de Justiça: doutrina. Edição comemorativa 20 anos. Brasília, DF, 2009. 
WEBBER, Suelen da Silva. Decisão, Risco e Saúde: o paradoxo da decisão judicial frente a pedidos de medicamentos experimentais. Curitiba: Juruá, 2013.

Data da submissão: 05 de fevereiro de 2016 Avaliado em: 11 de junho de 2016 (AVALIADOR A) Avaliado em: 08 de agosto de 2016 (AVALIADOR B) Aceito em: 04 de agosto de 2017 
